\title{
Films Formed on Carbon Steel in Sweet Environments - A Review
}

\author{
Igor A. Fioravante, ${ }^{a}$ Ronaldo S. Nunes, ${ }^{a}$ Heloisa A. Acciari ${ }^{a}$ and Eduardo N. Codaro ${ }^{\oplus *, a}$ \\ ${ }^{a}$ Faculdade de Engenharia, Universidade Estadual Paulista (Unesp), 12516-410 Guaratinguetá-SP, Brazil
}

\begin{abstract}
Corrosion of carbon steel pipelines in sweet environments has been extensively researched on oil and natural gas exploration and production in order to obtain efficient corrosion mitigation methods. Although the consequences of corrosion are known, the cause and mechanism by which a certain phenomenon occurs are still not well understood. Sweet corrosion is mainly caused by the carbon dioxide dissolved in the water contained in the oil. It can manifest itself in different ways and one of which is the formation of a scale on the inner walls of the pipelines, which determines the evolution of corrosion process. This paper discusses the effects of partial pressure of carbon dioxide, dissolved hydrogen sulfide, dissolved oxygen and water chemistry on scale formation. Particular attention is paid to the nature and stability of the aqueous species formed during the corrosion process, as well as the thermodynamic and kinetic aspects lead to the scale formation on the carbon steel surface. The main objective is to enhance the understanding of the conditions of formation and precipitation of siderite and mackinawite and their effects on corrosion processes involving low carbon steels.
\end{abstract}

Keywords: sweet corrosion, siderite, mackinawite, low carbon steels, carbon dioxide

\section{Introduction}

Corrosion has been a matter of concern for the oil and natural gas exploration and production industries due to pipes repair and replacement costs. These costs tend to increase as more hostile environments are found and high performance specifications are needed. Low carbon steels are the most commonly used materials because these are readily available in the market and can meet many of the mechanical, manufacturing and cost requirements. ${ }^{1-3}$ Despite these advantages, carbon steels have relatively low corrosion resistance and require qualification for use in environments containing carbon dioxide, hydrogen sulfide and brine. ${ }^{4-6}$ Corrosion occurs in several different ways, but two types are characteristic of these industries, sweet and sour corrosion. The former is the most frequent type and occurs in oils containing carbon dioxide at very high partial pressures. The latter type occurs in more acid oils containing hydrogen sulfide at partial pressures generally higher than 0.003 atm. ${ }^{7}$ There is no consensus about what partial pressures ratio of $\left(\mathrm{pCO}_{2} / \mathrm{pH}_{2} \mathrm{~S}\right)$ determines one or other type of corrosion, but ratios higher than 500 or lower than 20 appear to better classify sweet corrosion or sour corrosion, respectively. ${ }^{8-14}$ Once there is carbon dioxide

*e-mail: eduardo.codaro@unesp.br and brine in oil, it becomes a very aggressive environment that leads to the corrosion of the pipelines. When the inside walls of a pipeline suffer from corrosion, steel may lose its mechanical properties, which might lead to a catastrophic failure, causing huge losses. ${ }^{3,8,15}$ Pipelines can suffer localized or generalized attack, depending on carbon steel, oil and operating conditions such as pressure, temperature and fluid dynamics. Localized corrosion arises from the existence of galvanic pairs formed between the predominant phase (e.g., ferritic phase) and the nonmetallic (e.g., MnS) or intermetallic (e.g., $\mathrm{Fe}_{3} \mathrm{C}$ ) inclusions, ${ }^{16}$ and it commonly manifests as pitting or mesa attack. ${ }^{17,18}$ Generalized corrosion is a consequence of preferential dissolution of the predominant phase and it can be manifested by the formation of a mixed scale consisting principally of iron carbonate and cementite..$^{10,19,20}$ The structure of this scale plays an important role on the formation and mechanical stability of carbonate film. When carbon steel has sufficient carbon content to form a uniform distribution of cementite, it can develop a porous cementite layer on the carbon steel surface that provides an integrated structure to anchor and improve carbonate film adhesion. ${ }^{11,21}$ Variations in the fluid flow rate and/or fluid regime can change the type of attack, since the erosion caused by it can partially or totally remove the scale formed. ${ }^{22,23}$ Although corrosion consequences are known, causes and mechanisms by which 
each phenomenon occurs are still not well understood. There are four contributing factors to this situation, which are: varying chemical compositions of oil and produced water according to their deposits, wide range of operating conditions during oil extraction and transfer, limitations of laboratories to reproduce the actual internal conditions of pipelines, and a correlation of multiple parameters that influence corrosion.

Many experts of oil companies have studied the corrosive processes of carbon steels in sweet environments. Their hands-on experience combined with scientific research allowed discerning which corrosion products were somehow formed during oil extraction and production operations. Generally, a carbon steel pipeline contains a relatively continuous layer of iron oxides and oxyhydroxides (hematite $\mathrm{Fe}_{2} \mathrm{O}_{3}$, magnetite $\mathrm{Fe}_{3} \mathrm{O}_{4}$, lepidocrocyte $\gamma$ - $\mathrm{FeOOH}$, and goethite $\alpha-\mathrm{FeOOH}$ ) formed spontaneously in air, ${ }^{11}$ which is not removed before installation. ${ }^{24,25}$ As oil passes, $\mathrm{CO}_{2}$ and $\mathrm{H}_{2} \mathrm{~S}$ can react with these compounds to form carbonates, monosulfides and polysulfides. The chemical composition of corrosion products will depend on the $\mathrm{pCO}_{2} / \mathrm{pH}_{2} \mathrm{~S}$ ratio, oxygen contamination level and temperature. ${ }^{9,26,27}$

Researches, using different corrosion techniques in aqueous media, have made a significant contribution in this sense. Artificial sea water and other saline solutions containing different concentrations of carbon dioxide and hydrogen sulfide have often been used as corrosive media, probably due to these media having a similar chemical composition to emulsified water in oil. ${ }^{28,29}$ However, results obtained at relatively short exposure times at room temperature have led to one or two types of corrosion products, siderite or siderite plus mackinawite. ${ }^{11}$ Since the composition and physicochemical characteristics of corrosion products determine the evolution of corrosion process, the present work aims to broaden understanding about the conditions of formation and precipitation of siderite and mackinawite and their effects on corrosion processes involving low carbon steels.

\section{Discussion}

\subsection{Carbon dioxide in aqueous solution}

Carbon dioxide $\left(\mathrm{CO}_{2(\mathrm{~g})}\right)$ is a relatively water-soluble gas at room temperature (equation 1). When it is dissolved, it forms a very weak diprotic acid, also known as carbonic acid (equation 2). In literature, there are multiple dissociation constants for this acid $\left(\mathrm{K}_{\mathrm{a} 1}\right.$ and $\left.\mathrm{K}_{\mathrm{a} 2}\right)$, particularly for the second dissociation which involves very low concentrations of ionic species. In this study, intermediate values for $\mathrm{K}_{\mathrm{a} 1}$ and $\mathrm{K}_{\mathrm{a} 2}$ were used to calculate the equilibrium concentrations (equations 3 to 4 ). ${ }^{30}$

$$
\begin{aligned}
& \mathrm{CO}_{2(\mathrm{~g})} \leftrightarrows \mathrm{CO}_{2(\mathrm{aq})} \quad \mathrm{K}_{\mathrm{H}}=3.4 \times 10^{-2} \mathrm{~mol} \mathrm{~L}^{-1} \mathrm{~atm}^{-1} \\
& \mathrm{CO}_{2(\mathrm{aq})}+\mathrm{H}_{2} \mathrm{O}_{(\mathrm{l})} \leftrightarrows \mathrm{H}_{2} \mathrm{CO}_{3(\mathrm{aq})} \quad \mathrm{K}_{\mathrm{h}}=2.6 \times 10^{-3} \\
& \mathrm{H}_{2} \mathrm{CO}_{3(\mathrm{aq})} \leftrightarrows \mathrm{H}^{+}{ }_{(\mathrm{aq})}+\mathrm{HCO}_{3}^{-}(\mathrm{aq}) \quad \mathrm{K}_{\mathrm{a1}}=4.5 \times 10^{-7}
\end{aligned}
$$

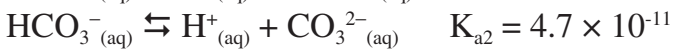

Given the low values of these constants and a broad difference between them, the $\mathrm{pH}$ of an aqueous solution can be determined by the first dissociation. Since the analytical concentration of $\mathrm{CO}_{2}$ is higher than its effective concentration, it is more appropriate to write an equilibrium expression involving the partial pressure of $\mathrm{CO}_{2}\left(\mathrm{pCO}_{2}\right)$. Although Henry's law is strictly aimed at gases that do not interact with the solvent, it is fulfilled for relatively low $\mathrm{pCO}_{2}$ values and ambient temperature. ${ }^{31}$ From Henry's law expression for $\mathrm{CO}_{2}$ in water, it is possible to obtain an equation relating $\mathrm{pH}$ and $\mathrm{pCO}_{2}$ (equation 5).

$\mathrm{pH}=3.91-0.50 \log \mathrm{pCO}_{2}$

Figure 1 shows a graphical representation of equation 5 . It reveals two characteristics of aqueous solutions of this gas: (i) saturated solutions are slightly acidic at ordinary pressures; (ii) to increase $\mathrm{pH}$ by one unit, it is necessary to decrease $\mathrm{pCO}_{2}$ by two orders of magnitude. In Figure 1, two additional dashed lines divide the graph into three regions and each one is formed by different $\mathrm{pH}$ and $\mathrm{pCO}_{2}$ conditions. Regions 1,2 and 3 were determined empirically and represent, respectively, low, medium and high corrosivity sweet environments for low-alloy carbon steels. For a given $\mathrm{pCO}_{2}, \mathrm{pH}$ mainly varies according to the relative concentration of formic and acetic acids present in produced water. ${ }^{32,33}$ This is one of the reasons why water chemistry can be a major contributor to pipeline corrosion.

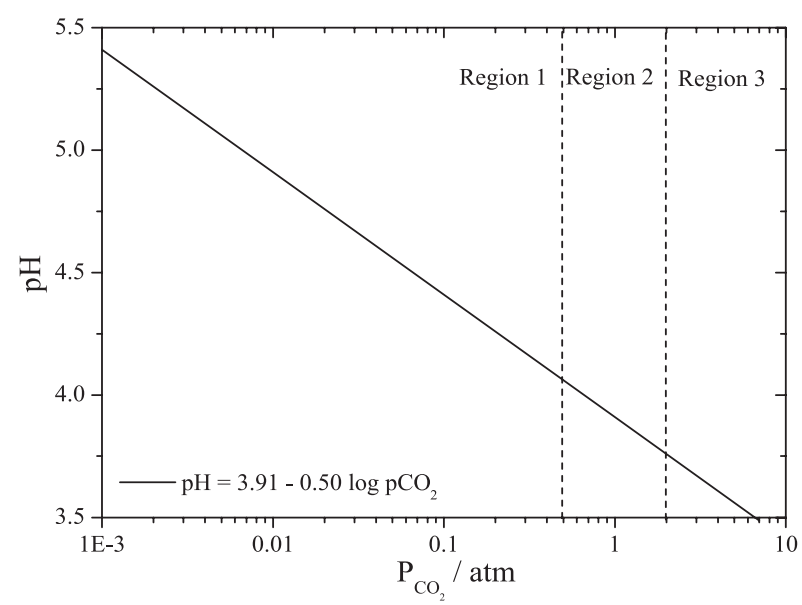

Figure 1. Effect of $\mathrm{pCO}_{2}$ on $\mathrm{pH}$ at $25^{\circ} \mathrm{C}$. 
If the solution $\mathrm{pH}$ is changed at constant $\mathrm{pCO}_{2}$ and temperature, equilibrium will be disturbed and a new carbon species ratio will be established. The relation between carbon-containing species and $\mathrm{pH}$ can be calculated from the mass balance equations. Figure 2 shows $\mathrm{H}_{2} \mathrm{CO}_{3 \text { (aq) }}$, $\mathrm{HCO}_{3}{ }^{-}$(aq) and $\mathrm{CO}_{3}{ }^{2-}$ (aq) fractional concentrations as a function of $\mathrm{pH}$ at $25^{\circ} \mathrm{C}$. At $\mathrm{pH}<4.0, \mathrm{CO}_{2 \text { (aq) }}$ and $\mathrm{H}_{2} \mathrm{CO}_{3 \text { (aq) }}$ are the predominant species, mainly the first one, since the other one is less than $0.01 \% .{ }^{34}$ For $6.3<\mathrm{pH}<10.3$, $\mathrm{HCO}_{3}^{-}$(aq) $\mathrm{HCO}_{3}^{-}$(aq) and $\mathrm{CO}_{3}{ }^{2-}$ (aq) are important. It is worth mentioning that in acid solutions there are small concentrations of $\mathrm{CO}_{3}{ }^{2-}{ }_{\text {(aq) }}$ that are ready to react, but only the most insoluble carbonates can precipitate. ${ }^{35} \mathrm{In}$ this figure the two regions of buffer efficiency corresponding to $\mathrm{H}_{2} \mathrm{CO}_{3(\text { (aq })} / \mathrm{HCO}_{3}^{-}$(aq)

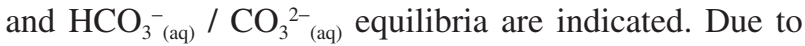
the first conjugate acid-base pair, it is expected that during corrosion of the carbon steel in acidic medium, the $\mathrm{pH}$ will increase until it reaches the first buffer $\mathrm{pH}$ range and then stabilizes. To maintain a constant $\mathrm{pH}$ value, carbon dioxide produces carbonic acid (equation 2). As this reaction must cause the diffusion of the dissolved carbon dioxide from the oil to the aqueous phase, ${ }^{36,37}$ the capacity of the buffer must remain unchanged.

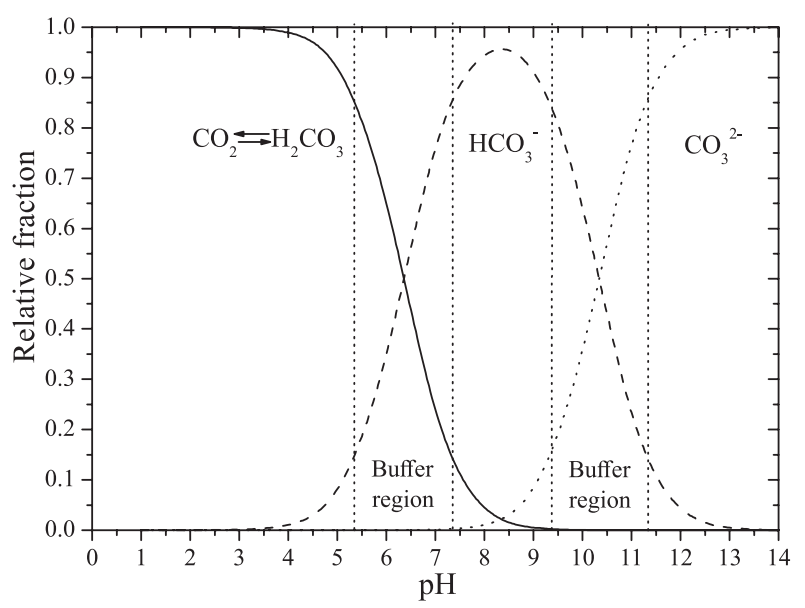

Figure 2. Carbon-containing species as a function of $\mathrm{pH}$.

In the Pourbaix diagram of Figure 3 are indicated the stability regions of species containing organic and inorganic carbon as a function of electrode potential and $\mathrm{pH} .{ }^{38}$ The organic carbon was represented by formic acid which is often found in oil and in the produced water in a greater proportion than other organic acids. ${ }^{32,33}$ Vertical lines correspond to different acid-base equilibria. The $\mathrm{pH}$ values for these equilibria were calculated from the $\mathrm{p} K$ of formic and carbonic acids. Two dotted lines were added to the diagram in order to indicate the water stability region. The species within this region do not react with $\mathrm{H}_{2} \mathrm{O}$, whilst those outside are able to do so. Therefore, it is verified that $\mathrm{H}_{2} \mathrm{CO}_{3 \text { (aq) }}, \mathrm{HCO}_{3}^{-}$(aq) and $\mathrm{CO}_{3}{ }^{2-}$ (aq) are stable in aqueous solutions throughout the $\mathrm{pH}$ range, while $\mathrm{HCO}_{2} \mathrm{H}_{(\text {aq) }}$ and $\mathrm{HCO}_{2}^{-}$(aq) are unstable throughout the $\mathrm{pH}$ range, both in the presence and absence of oxygen. This suggests that the dissolved formic acid in oil can act as a carbonic acid source increasing the buffer capacity as the corrosion reaction proceeds.

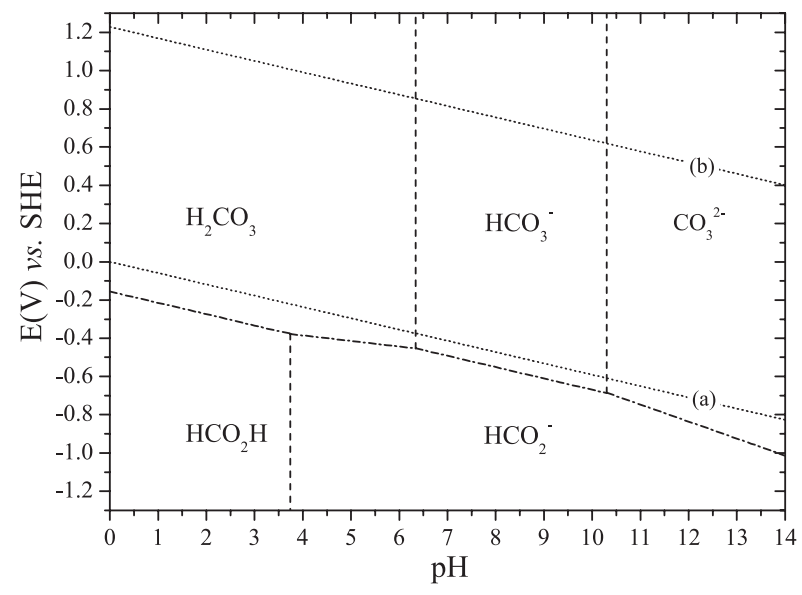

Figure 3. Simplified Pourbaix diagram for the $\mathrm{C}-\mathrm{H}_{2} \mathrm{O}$ system at $25^{\circ} \mathrm{C}$.

\subsection{Iron in aqueous solution}

Figure 4 illustrates simplified Pourbaix diagrams for the $\mathrm{Fe}-\mathrm{H}_{2} \mathrm{O}$ system at $25{ }^{\circ} \mathrm{C}$, which show stability regions of the different species involved. ${ }^{30}$ These were constructed from possible chemical and electrochemical reactions associated with iron in wet or aqueous conditions, except for those that generate products with insufficient information, such as oxyanions. Since $\mathrm{Fe}^{2+}{ }_{\text {aq) }}$ is the initial product of acid corrosion, its concentration was considered 100 times higher than the $\mathrm{Fe}^{3+}$ (aq) concentration. The latter

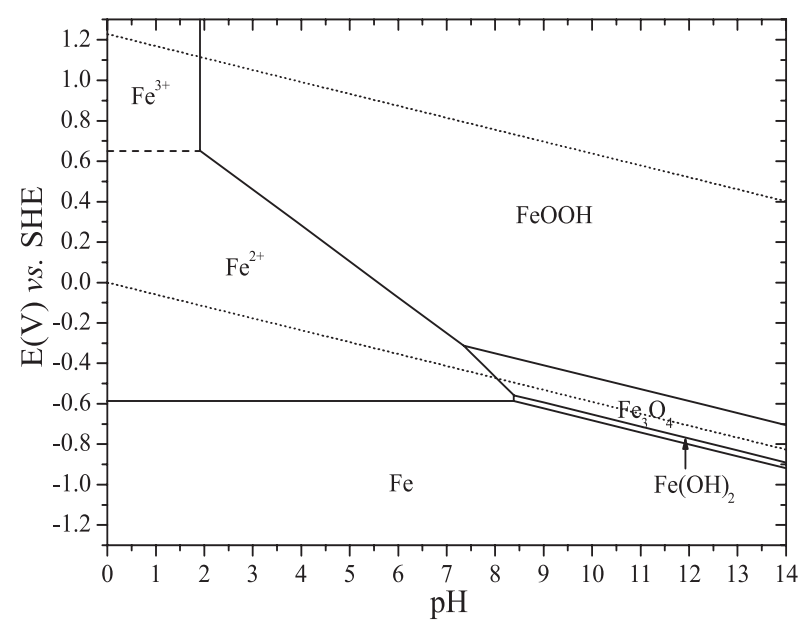

Figure 4. Simplified Pourbaix diagram for the $\mathrm{Fe}-\mathrm{H}_{2} \mathrm{O}$ system at $25^{\circ} \mathrm{C}$ with passivity domain formed by $\mathrm{Fe}(\mathrm{OH})_{2(\mathrm{~s})}, \mathrm{Fe}_{3} \mathrm{O}_{4(\mathrm{~s})}$ and $\mathrm{FeOOH}_{(\mathrm{s})}$. 
was set at $10^{-6} \mathrm{~mol} \mathrm{~L}^{-1}$, i.e., often found for mineral acids. Its two dotted lines enclose the water stability region and a corrosion reaction can occur as $\mathrm{Fe}_{(\text {aq })}^{2+} / \mathrm{Fe}_{(\mathrm{s})}$ reduction potential is below one of these lines.

According to the diagrams, it should be noted that iron may be oxidized throughout this $\mathrm{pH}$ range, but the oxidation product will depend on the oxidizing agent. At $\mathrm{pH}<8.4$, the anodic reaction product is $\mathrm{Fe}^{2+}{ }_{\text {(aq) }}$ (shorthand notations for $\left[\mathrm{Fe}\left(\mathrm{H}_{2} \mathrm{O}\right)_{6}\right]^{2+}$ or $\left.[\mathrm{FeOH}]^{+}\right)$, and $\mathrm{Fe}(\mathrm{OH})_{2(\mathrm{~s})}$ and $\mathrm{Fe}_{3} \mathrm{O}_{4(\mathrm{~s})}$ for $8.4 \leq \mathrm{pH} \leq 14$. It is worth mentioning that $\mathrm{Fe}(\mathrm{OH})_{2(\mathrm{~s})}$ is not necessarily a precursor of $\mathrm{Fe}_{3} \mathrm{O}_{4(\mathrm{~s})}$, the latter can also be formed at lower $\mathrm{pH}$ values. In the presence of oxygen, the medium becomes more oxidizing and $\mathrm{Fe}^{\mathrm{II}}$-containing species can be oxidized into $\mathrm{Fe}^{3+}{ }_{\text {(aq) }}$ (shorthand notations for $\left[\mathrm{Fe}\left(\mathrm{H}_{2} \mathrm{O}\right)_{6}\right]^{3+}$ or $\left.[\mathrm{FeOH}]^{2+}\right)$ and $\mathrm{FeOOH}_{(\mathrm{s})}$, depending on the $\mathrm{pH}$ value. Three domains can be differentiated through these diagrams: corrosion (composed of iron cations), immunity (consisting of pure iron) and passivity (consisting in a film that supposedly protects iron). These regions represent theoretical conditions in which corrosion may, cannot and does not occur, respectively.

In practice, a source of oxygen contamination is from manipulating the fluids used in the secondary and tertiary oil recovery. This is a serious problem, since the depolarizing action of oxygen can increase the corrosion rate of low carbon steel by up to two orders of magnitude. ${ }^{28,29}$ If produced water is used in oil recovery, the concentration of dissolved oxygen greatly depends on salinity. ${ }^{32,33}$ When it is low, the most frequently found corrosion products in pipelines are $\alpha-\mathrm{FeOOH}, \beta-\mathrm{FeOOH}$ and $\gamma-\mathrm{FeOOH}$, otherwise $\alpha-\mathrm{Fe}_{2} \mathrm{O}_{3}$ is the main product. ${ }^{9,39}$

\subsection{Iron in carbon dioxide solution}

When iron is exposed to a carbon dioxide solution, a corrosion reaction occurs whose consequence may be carbonate precipitation. As the concentration of ionic species in this medium is directly linked to $\mathrm{pH}$, the possibility of whether carbonate will precipitate or not also depends on $\mathrm{pH}$. There are different expressions in literature that determine the solubility equilibrium and several constants for these equilibria. ${ }^{34,40}$ In this study, it was used expressions of solubility products of $\mathrm{Fe}(\mathrm{OH})_{2}$ and $\mathrm{FeCO}_{3}$ (siderite) at $25{ }^{\circ} \mathrm{C}$ described by equations 6 and 7 , respectively.

$$
\begin{aligned}
& \mathrm{K}_{\mathrm{sp}, \mathrm{Fe}(\mathrm{OH})_{2}}=\frac{\left[\mathrm{Fe}^{2+}\right]}{\left[\mathrm{H}^{+}\right]^{2}}=1.6 \times 10^{-13} \\
& \mathrm{~K}_{\mathrm{sp}, \mathrm{FeCO}_{3}}=\frac{\left[\mathrm{Fe}^{2+}\right] \mathrm{pCO}_{2}}{\left[\mathrm{H}^{+}\right]^{2}}=8.6 \times 10^{5}
\end{aligned}
$$

By rearranging the equations 6 and 7, it is possible to obtain the equations 8 and 9 , which can clarify the influence of $\mathrm{pH}$ on solubility equilibria.

$\log \left[\mathrm{Fe}^{2+}\right]=12.8-2 \mathrm{pH}$

$\log \left[\mathrm{Fe}^{2+}\right]=5.93-\log \mathrm{pCO}_{2}-2 \mathrm{pH}$

The influence of $\mathrm{pH}$ on the $\mathrm{FeCO}_{3}$ and $\mathrm{Fe}(\mathrm{OH})_{2}$ solubilities is shown in Figure 5. One additional line was plotted representing the solubility equilibrium of mackinawite (equation 10), which can be formed at very low $\mathrm{pH}_{2} \mathrm{~S}$. $^{41,42}$ This sulfide is formed rapidly over a wide range of partial pressures and temperatures and is relatively stable in oxygen free acid medium. ${ }^{43}$

$\log \left[\mathrm{Fe}^{2+}\right]=4.19-\log \mathrm{pH}_{2} \mathrm{~S}-2 \mathrm{pH}$

Each line divides the graph into two regions: the dissolution region on the left and the precipitation region on the right. It is evident that when $\mathrm{pCO}_{2}$ is increased, lower concentrations of $\mathrm{Fe}^{2+}{ }_{(\mathrm{aq})}$ are sufficient to precipitate $\mathrm{FeCO}_{3}$, and there is a $\mathrm{pCO}_{2}$ from which the concentration in equilibrium with $\mathrm{FeCO}_{3(\mathrm{~s})}$ is lower than that required to precipitate $\mathrm{FeS}$. It can be deduced from equations 9 and 10 that when the $\mathrm{pCO}_{2} / \mathrm{pH}_{2} \mathrm{~S}$ ratio is more than 55 , the corrosion may be considered sweet.

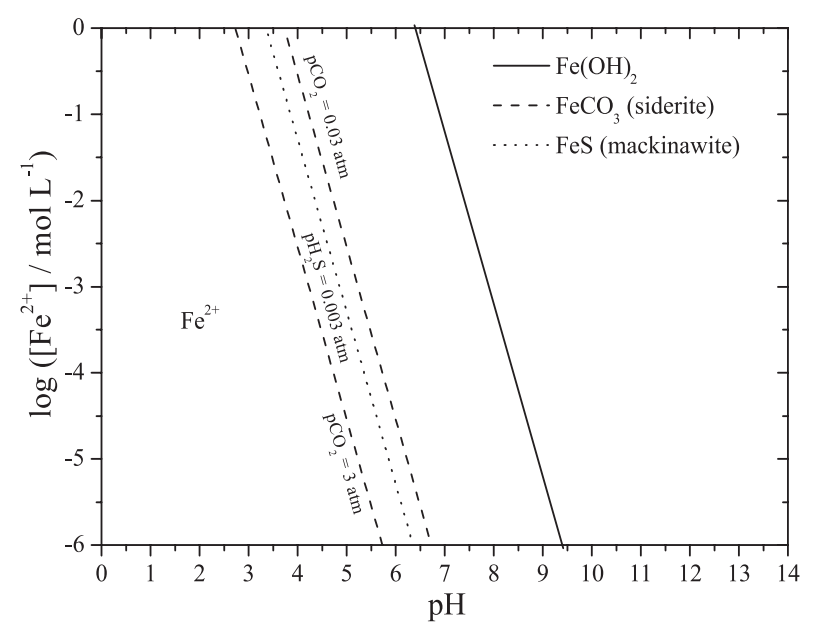

Figure 5. $\mathrm{pH}$ influence on solubilities of $\mathrm{FeCO}_{3}$ (siderite), $\mathrm{FeS}$ (mackinawite) and $\mathrm{Fe}(\mathrm{OH})_{2}$ at $25^{\circ} \mathrm{C}$.

$\mathrm{FeCO}_{3}$ precipitation will start when $\mathrm{Fe}^{2+}{ }_{(\text {aq) }}$ concentration and $\mathrm{pH}$ are the same as those in the line. Then, the ionic product $\left[\mathrm{Fe}^{2+}\right]\left[\mathrm{CO}_{3}{ }^{2-}{ }_{\text {(aq) }}\right]$ value will be the same as that of $\mathrm{K}_{\mathrm{sp}, \mathrm{FeCO} 3}$. Since $\mathrm{OH}^{-}$(aq) and $\mathrm{CO}_{3}{ }^{2-}{ }_{(\mathrm{aq})}$ concentrations are defined according to Figure 2, the ionic product $\left[\mathrm{Fe}^{2+}\right]\left[\mathrm{OH}^{-}\right]^{2}$ is always less than $\left[\mathrm{Fe}^{2+}\right]\left[\mathrm{CO}_{3}{ }^{2-}\right]$, and thus there is no precipitation of $\mathrm{Fe}(\mathrm{OH})_{2}$ in a sweet environment. If it is present before oil passes through the pipeline, 
it will react with carbon dioxide and form carbonate (equation 11). ${ }^{30}$

$$
\begin{array}{r}
\mathrm{Fe}(\mathrm{OH})_{2(\mathrm{~s})}+\mathrm{CO}_{2(\text { aq) }} \rightarrow \mathrm{FeCO}_{3(\mathrm{~s})}+\mathrm{H}_{2} \mathrm{O}_{(\mathrm{l})} \\
\Delta \mathrm{G}^{0}=-38.98 \mathrm{~kJ}
\end{array}
$$

Pourbaix diagrams of iron in the presence of $\mathrm{CO}_{\text {2(aq) }}$ are shown in Figure 6. For constructing these diagrams, equations 9 and 12 were used to represent chemical equilibria. Nernst equations 13 and 14 were obtained using $\Delta \mathrm{G}_{f}^{0}\left(\mathrm{FeCO}_{3}\right)=-680.0 \mathrm{~kJ} \mathrm{~mol}^{-1}, \Delta \mathrm{G}_{f}^{0}\left(\mathrm{CO}_{2}\right)=-386.2 \mathrm{~kJ} \mathrm{~mol}^{-1}$ and $\Delta \mathrm{G}_{f}^{0}(\alpha-\mathrm{FeOOH})=-492.1 \mathrm{~kJ} \mathrm{~mol}^{-1}{ }^{10}$ By comparing Figure 6 to Figure 4, it can be concluded that the former has a larger passivation domain due to carbonate formation.

$\log \left[\mathrm{Fe}^{3+}\right]=-0.269-3 \mathrm{pH}$

$\mathrm{E}\left(\mathrm{FeCO}_{3} / \mathrm{Fe}\right)=-0.294-0.296 \log \mathrm{pCO}_{2}-$ $0.0591 \mathrm{pH}$

$\mathrm{E}\left(\mathrm{FeOOH} / \mathrm{FeCO}_{3}\right)=0.403+0.0591 \log \mathrm{pCO}_{2}-$ $0.0591 \mathrm{pH}$

Similar Pourbaix diagrams were constructed by other authors ${ }^{44}$ in the temperature range from 25 to $80{ }^{\circ} \mathrm{C}$. They had demonstrated that an increase in $\mathrm{pCO}_{2}$ or temperature favors the formation of carbonate, but film formation was observed only at temperatures higher than $55^{\circ} \mathrm{C} .4^{44-46}$

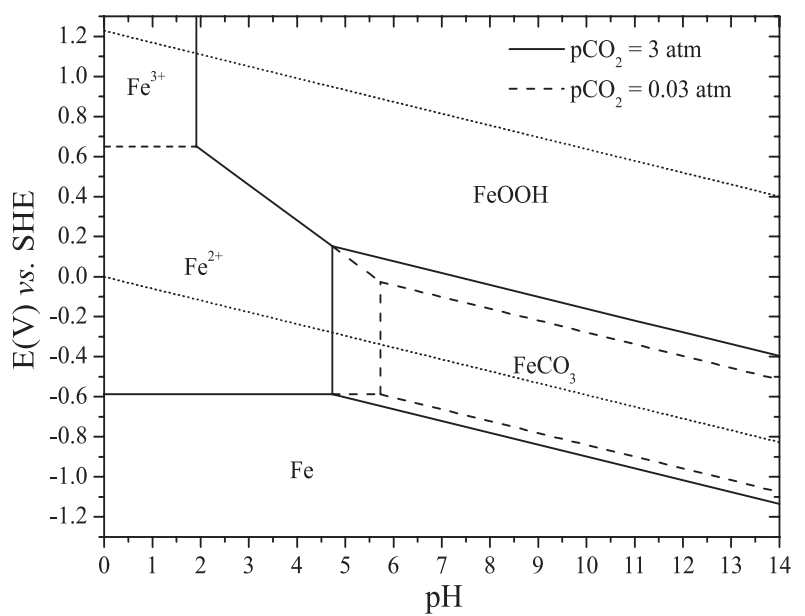

Figure 6. Simplified Pourbaix diagrams for the $\mathrm{Fe}-\mathrm{H}_{2} \mathrm{O}-\mathrm{CO}_{2}$ system at $25^{\circ} \mathrm{C}$ considering the effect of $\mathrm{pCO}_{2}$ on siderite formation.

A more detailed analysis of Figure 6 reveals that for $\mathrm{pCO}_{2}=3.0$ atm and $\mathrm{pH}<4.73$, conditions are not favorable for siderite film formation (region 3 in Figure 1) and $\mathrm{Fe}^{\mathrm{II}}$ soluble species are the most stable in the absence of oxygen. In this $\mathrm{pH}$ range, $\mathrm{Fe}^{2+}{ }_{\text {(aq) }}$ and $\mathrm{HCO}_{3}{ }^{-}$(aq) are the predominant ionic species (Figure 7), which can react to form $\mathrm{FeHCO}_{3}{ }^{+}{ }_{\text {(aq) }}\left(\mathrm{K}_{\mathrm{f}} \mathrm{ca}\right.$. 28). At higher $\mathrm{pH}$, another stable complex can be formed $\mathrm{FeCO}_{3}{ }^{0}$ (aq) $\left(\mathrm{K}_{\mathrm{f}}\right.$ ca. 50000$),{ }^{30}$ and both the former and the latter can shift the solubility equilibrium to higher $\mathrm{pH}$ values, favoring the dissolution of iron. ${ }^{47}$ The information in the literature on these complexes is very limited and there is no strong experimental evidence for the formation of $\mathrm{Fe}^{\mathrm{II}}$-carbonate complexes in acid medium, since the protonation of a carbonate ligand generally leads to a rapid release of carbon dioxide. ${ }^{48}$

At $\mathrm{pH} \geq 4.73$, iron is also oxidized and $\mathrm{FeCO}_{3}$ can precipitate and form a film. However, when the electrolyte is produced water, it is necessary to consider the effect of ionic strength on the solubility, since produced water is a solution of high salinity. The higher ionic strength of the medium, the lower effective concentration of $\mathrm{Fe}^{2+}{ }_{\text {(aq) }}$ and $\mathrm{CO}_{3}{ }^{2-}$ (aq), , therefore $\mathrm{FeCO}_{3}$ precipitation will occur at higher $\mathrm{pH}$ values. ${ }^{32,33,49}$

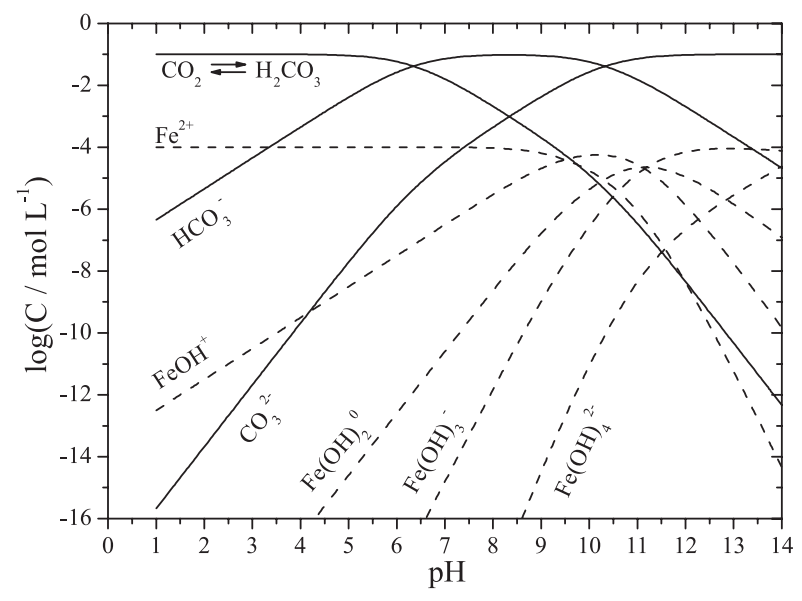

Figure 7. Distribution curves of carbon- and iron-containing species.

When the $\mathrm{pCO}_{2}$ is increased, the passivation region increases and the corrosion region decreases as a consequence of smaller metal active area due to a protective film formation. However, due to the high concentration of species that can be reduced at low $\mathrm{pH}$ values $\left(\mathrm{H}^{+}{ }_{\text {(aq) }}, \mathrm{CO}_{2(\mathrm{aq})}\right.$ and $\mathrm{H}_{2} \mathrm{CO}_{3 \text { (aq) }}$ ), the dissolution rate of iron is higher than the precipitation rate of carbonate, and thus the film formation does not occur. ${ }^{10,11,15}$ Researches confirm that carbonate precipitation does not occur at $\mathrm{pH}<5.0$ and corrosion of carbon steels is generalized at room temperature. Films formed between $\mathrm{pH} 5.0$ and 6.0 are discontinuous or porous and those formed at $\mathrm{pH}>6.0$ are dense. ${ }^{10,11,44,50} \mathrm{In}$ the presence of oxygen, the $\mathrm{Fe}^{\mathrm{II}}$-containing species can be oxidized to form $\mathrm{Fe}^{3+}{ }_{\text {(aq) }}$ or $\mathrm{FeOOH}_{(\mathrm{s})}$ (equation 15), depending on the $\mathrm{pH}$.

$$
\begin{array}{r}
4 \mathrm{FeCO}_{3(\mathrm{~s})}+\mathrm{O}_{2(\mathrm{~g})}+2 \mathrm{H}_{2} \mathrm{O}_{(\mathrm{l})} \rightarrow 4 \alpha-\mathrm{FeOOH}_{(\mathrm{s})}+4 \mathrm{CO}_{2(\text { aq })} \\
\Delta \mathrm{G}^{0}=-318.8 \mathrm{~kJ}
\end{array}
$$




\subsection{Carbon steel corrosion}

When low carbon steel is exposed to a sweet environment, it is corroded and releases $\mathrm{Fe}^{2+}{ }_{(\mathrm{aq})}$ and $\mathrm{H}_{2(\mathrm{~g})}$. Secondary phases such as cementite or other carbides can act as cathodes, while the iron dissolution occurs in the ferrite and pearlite grains, for example. At $\mathrm{pH}<4.0$, iron has two major alternative routes for dissolution: in strongly acid medium, it occurs through adsorbed $\mathrm{Fe}^{\mathrm{II}}$-hydroxo species on the metal surface (equations 16, 17 and 18), and in moderately acid medium, it is promoted by intermediate

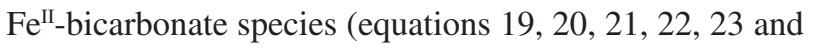
24). For each mechanism below, the rate-determining step (rds) is indicated. ${ }^{15,47,51}$

$$
\begin{aligned}
& \mathrm{Fe}_{(\mathrm{s})}+\mathrm{H}_{2} \mathrm{O}_{(\mathrm{l})} \rightarrow \mathrm{FeOH}_{(\mathrm{ad})}+\mathrm{H}^{+}{ }_{(\mathrm{aq})}+\mathrm{e}^{-} \\
& \mathrm{FeOH}_{(\mathrm{ad})} \rightarrow \mathrm{FeOH}^{+}{ }_{(\mathrm{ad})}+\mathrm{e}^{-} \\
& \mathrm{FeOH}_{(\mathrm{ad})}^{+}+\mathrm{H}^{+}{ }_{(\mathrm{aq})} \leftrightarrows \mathrm{Fe}^{2+}{ }_{(\mathrm{aq})}+\mathrm{H}_{2} \mathrm{O}_{(\mathrm{l})} \\
& \mathrm{Fe}_{(\mathrm{s})}+\mathrm{CO}_{2(\mathrm{aq})} \leftrightarrows \mathrm{FeCO}_{2(\mathrm{ad})} \\
& \mathrm{FeCO}_{2(\mathrm{ad}))}+\mathrm{H}_{2} \mathrm{O}_{(\mathrm{l})} \leftrightarrows \mathrm{FeHCO}_{3(\mathrm{ad})}+\mathrm{H}_{(\mathrm{aq})}^{+}+\mathrm{e}^{-} \\
& \mathrm{FeHCO}_{3(\mathrm{ad})} \leftrightarrows \mathrm{FeHCO}_{3}^{+}{ }_{(\mathrm{ad})}+\mathrm{e}^{-} \\
& \mathrm{FeHCO}_{3}^{+}{ }_{(\mathrm{ad})}+\mathrm{H}_{2} \mathrm{O}_{(\mathrm{l})} \leftrightarrows \mathrm{FeOH}_{2} \mathrm{CO}_{3(\mathrm{ad})}+\mathrm{H}^{+}{ }_{(\mathrm{aq})} \\
& \mathrm{FeOH}_{2} \mathrm{CO}_{3(\mathrm{ad})} \leftrightarrows \mathrm{FeOH}_{2} \mathrm{CO}_{3(\mathrm{aq})} \quad(\mathrm{rds}) \\
& \mathrm{FeOH}_{2} \mathrm{CO}_{3(\mathrm{aq})}+2 \mathrm{H}_{(\mathrm{aq})} \leftrightarrows \mathrm{Fe}_{(\mathrm{aq})}+\mathrm{CO}_{2(\mathrm{aq})}+2 \mathrm{H}_{2} \mathrm{O}_{(\mathrm{l})}
\end{aligned}
$$

Some authors ${ }^{52,53}$ indicate that the iron dissolution rate depends on the amount, distribution and morphology of the cementite phase.Others suggest that it depends mainly on the concentration of species that carbon dioxide produces at the metal/electrolyte interface ${ }^{47,54}$ Others argue that the cathodic reaction controls the corrosion reaction through a series of steps involving the reduction of $\mathrm{H}^{+}{ }_{\text {(aq) }}$ (equation 25) or $\mathrm{H}_{2} \mathrm{CO}_{3(\mathrm{ad})}$ (equation 26) on the metal surface, this mechanism is known as direct reduction (equations 26, 27 and 28). ${ }^{11,19,47,55,56}$

$$
\begin{aligned}
& \mathrm{H}^{+}{ }_{(\mathrm{aq})}+\mathrm{e}^{-} \rightarrow \mathrm{H}_{(\mathrm{ad})} \\
& \mathrm{H}_{2} \mathrm{CO}_{3(\mathrm{ad})}+\mathrm{e}^{-} \rightarrow \mathrm{HCO}_{3}^{-}{ }_{(\mathrm{ad})}+\mathrm{H}_{(\mathrm{ad})} \quad(\mathrm{rds}) \\
& \mathrm{H}_{2} \mathrm{CO}_{3(\mathrm{ad})}+\mathrm{H}_{(\mathrm{ad})}+\mathrm{e}^{-} \rightarrow \mathrm{HCO}_{3}^{-}{ }_{(\mathrm{ad})}+\mathrm{H}_{2(\mathrm{~g})} \\
& \mathrm{H}_{(\mathrm{ad})}+\mathrm{H}_{(\mathrm{ad})} \rightarrow \mathrm{H}_{2(\mathrm{~g})}
\end{aligned}
$$

As $\mathrm{pH}$ increases, all equilibria involving the participation of $\mathrm{H}^{+}{ }_{(\mathrm{aq})}$ are shifted so that the concentration of other ions is altered (Figure 7). In the $\mathrm{pH}$ range of 5.3 to 6.3, the $\mathrm{pH}$ tends to maintain in a constant value due to the $\mathrm{H}_{2} \mathrm{CO}_{3(\mathrm{aq})} / \mathrm{HCO}_{3}^{-}$(aq) pair (Figure 2) and $\mathrm{H}^{+}$(aq) is replenished as it is consumed in the cathodic reaction, this mechanism is known as buffering effect. ${ }^{47}$ In this $\mathrm{pH}$ range, conditions are favorable for the siderite formation, therefore, when the ionic product $\left[\mathrm{Fe}^{2+}{ }_{(\mathrm{aq})}\right]\left[\mathrm{CO}_{3}{ }^{2-}{ }_{(\mathrm{aq})}\right]$ exceeds the solubility limit, the precipitation can occur on the metal surface, and both $\mathrm{pH}$ and $\mathrm{Fe}^{2+}{ }_{\text {(aq) }}$ concentration must remain constant (Figure 5). ${ }^{15,57} \mathrm{FeCO}_{3(\mathrm{~s})}$ formation is believed to occurs in a one-step reaction from its constituent ions (equation 29), but a two-step reaction involving a $\mathrm{Fe}^{\mathrm{II}}$-bicarbonate specie (equations 30 and 31) has also been suggested. ${ }^{21}$ Although $\mathrm{FeCO}_{3}$ precipitation is possible, the rate at which this phenomenon occurs is very slow at temperatures lower than $80^{\circ} \mathrm{C}$ and relatively long exposure times are required for the formation and growth of a film. ${ }^{10,31,58}$

$\mathrm{Fe}^{2+}{ }_{(\mathrm{aq})}+\mathrm{CO}_{3}{ }^{2-}$ (aq) $\rightarrow \mathrm{FeCO}_{3(\mathrm{~s})}$

$\mathrm{Fe}^{2+}{ }_{(\mathrm{aq})}+2 \mathrm{HCO}_{3}^{-}{ }_{(\mathrm{aq})} \rightarrow \mathrm{Fe}\left(\mathrm{HCO}_{3}\right)_{2(\mathrm{~s})}$

$\mathrm{Fe}\left(\mathrm{HCO}_{3}\right)_{2(\mathrm{~s})} \rightarrow \mathrm{FeCO}_{3(\mathrm{~s})}+\mathrm{CO}_{2(\mathrm{~g})}+2 \mathrm{H}_{2} \mathrm{O}_{(\mathrm{l})}$

At $\mathrm{pH}>6.0$, another cathodic reaction may participate in the mechanism (equations 32 or 33), but the presence of a film can determine the corrosion reaction control. In this sense, the siderite film may restrict or block the transport of species to and from the metal surface and thus decrease the corrosion rate. ${ }^{59}$

$$
\begin{aligned}
& 2 \mathrm{H}_{2} \mathrm{O}_{(\mathrm{l})}+2 \mathrm{e}^{-} \rightarrow 2 \mathrm{OH}^{-}{ }_{(\mathrm{aq})}+\mathrm{H}_{2(\mathrm{~g})} \\
& \mathrm{HCO}_{3}^{-}{ }_{(\mathrm{aq})}+\mathrm{e}^{-} \rightarrow \mathrm{CO}_{3}^{2-}{ }_{(\mathrm{aq})}+\mathrm{H}_{(\mathrm{ad})}
\end{aligned}
$$

In the presence of trace amounts of $\mathrm{H}_{2} \mathrm{~S}_{(\mathrm{aq})}$ (on the order of some ppm), a thin layer of mackinawite $(<<1.0 \mu \mathrm{m})$ is quickly formed, probably through a solid-state mechanism from adsorbed species (e.g., $\mathrm{HS}^{-}{ }_{\text {(ad) }}$ or $\mathrm{FeSH}^{-}{ }_{\text {(ad) }}$ ) at the metal/ electrolyte interface..$^{10,27,41,60-63}$ This is based on a certain similarity between unit cells of tetragonal mackinawite and the body-centered cubic ferritic structure of carbon steel..$^{27,60}$ Due to its high electrical conductivity, ${ }^{64} \mathrm{H}^{+}{ }_{(\mathrm{aq})}, \mathrm{H}_{2} \mathrm{CO}_{3(\mathrm{aq})}$ or $\mathrm{HCO}_{3}^{-}{ }_{(\mathrm{aq})}$ species can be reduced on the film surface, thus causing iron oxidation. ${ }^{65-68}$ The nucleation and growth of $\mathrm{FeCO}_{3(\mathrm{~s})}$ will occur if the local conditions at the film/ electrolyte interface favor the formation of this new phase.

\section{Summary}

When low carbon steel is exposed to sweet environments, a corrosion process is initiated. Partial pressure of $\mathrm{CO}_{2(\mathrm{~g})}$ and water chemistry are two of the main contributors to this process. The corrosion can occurs through different mechanisms depending on the $\mathrm{pH}$. In strongly acid medium, the iron dissolution mechanism involves adsorbed $\mathrm{Fe}^{\mathrm{II}}$-hydroxo species on the metal surface, which control the corrosion rate. In moderately acid medium, the mechanism involves intermediate $\mathrm{Fe}^{\mathrm{II}}$-bicarbonate species and its rate-determining step has not been well-established yet. In slightly acid or neutral media, siderite can precipitate, but the presence of complexing agents and the ionic 
strength of the medium can determine at what $\mathrm{pH}$ value this phenomenon will occur. After the siderite nucleation, it is likely to grow through a dissolution-precipitation mechanism and the diffusion of the species to or from the metal surface may control the corrosion rate.

If hydrogen sulfide was originally present, it would react quickly with iron to form mackinawite. When a layer is formed on the metal surface, the corrosion rate is diminished and the corrosion process continues until it is inhibited by formation of a siderite layer. In the absence of oxygen, other solid species such as oxides and oxyhydroxides of iron(III) must not be formed during sweet corrosion, but they can be present before oil passes through the pipeline or they can be formed due to the entry of oxygen into the pipeline during oil recovery operations. The degree of oxygen contamination will determine the relative proportions of these compounds in the corrosion products. Although these conclusions can enhance the understanding of sweet corrosion, there are still several unclear aspects that require more attention. It is well-known that carbonate precipitation does not occur at high partial pressures of $\mathrm{CO}_{2(\mathrm{~g})}$ and low $\mathrm{pH}$ values at room temperature, but what is the set of parameters really lead to formation of a protective carbonate film? What is the range of partial pressures of $\mathrm{H}_{2} \mathrm{~S}_{(\mathrm{g})}$ that decreases the corrosion rate by forming a sulfide film? How the native oxides and oxyhydroxides affect the formation and protectiveness of a sulfide or carbonate film? To what extent do the protective characteristics of these films change in the presence of small amounts of dissolved oxygen?

\section{Acknowledgments}

This work has been supported by the São Paulo Research Foundation (grant No. 2017/11361-5).

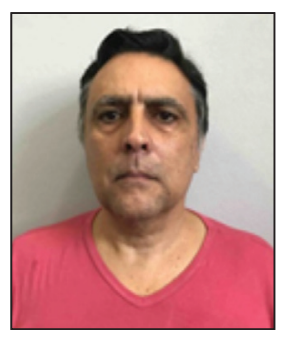

Eduardo Norberto Codaro was born in Buenos Aires in Argentina in the early 1960s. He graduated in chemistry from the National University of La Plata (UNLP) and PhD in chemistry from the Institute of Theoretical and Applied Physical-Chemical Research (INIFTA-UNLP) in 1996. He has been a Professor of Chemistry in São Paulo State University (UNESP) in Brazil since 2003. He has published over 70 scientific papers (h-index 13) on chemical and electrochemical behavior of several metals and alloys in different aqueous media, but his main research interests are the thermodynamics and kinetics of sour and sweet corrosion of carbon steels.

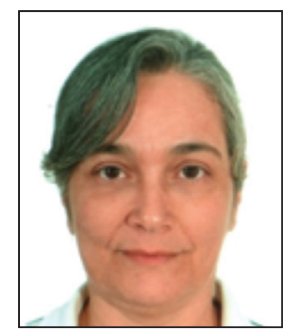

Heloisa Andréa Acciari is a bachelor in chemistry from the São Paulo University (1994), MSc in chemistry (1997) and PhD in Chemistry (2001), Post Doctoral researcher in biomaterial corrosion (2003), Post Doctoral researcher biohydrometallurgy processes (2008) at Institute of Chemistry, São Paulo State University (UNESP). She has been a professor of chemistry at School of Engineering, São Paulo State University (UNESP) since 2010. She is currently assistant professor at São Paulo State University (UNESP). Her main research interests are the ac and dc anodisation processes of titanium and its alloys.

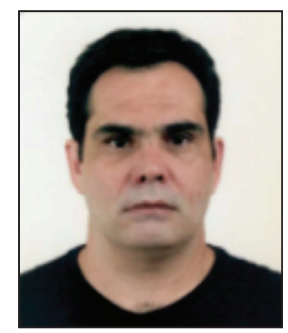

Ronaldo S. Nunes holds a bachelor's degree in Chemistry (2001) from the Federal University of São Carlos (UFSCar). In 2004, he obtained his MSc degree in analytical chemistry from the Institute of Chemistry of São Carlos, University of São Paulo (USP). In 2009, he received his $P h D$ in analytical chemistry at the same institution. His main areas of research are thermal analysis of transition metal and lanthanide complexes and chemical equilibrium in aqueous solution. He is currently a full-time chemistry professor at the Engineering School, São Paulo State University (UNESP).

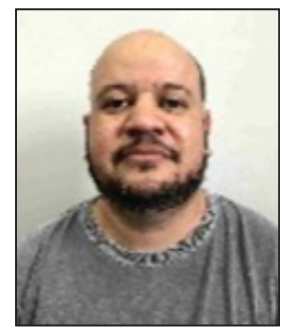

Igor Alexandre Fioravante graduated in industrial production from the State Center for Technological Education Paula Souza in 2008 and master in product design from the Teresa D'Ávila University Center (UNIFATEA) in 2017. He is currently a PhD student researching the sweet corrosion of low alloy carbon steels at the São Paulo State University (UNESP).

\section{References}

1. International Energy Agency (IEA); Resources to Reserves 2013 - Oil, Gas and Coal Technologies for the Energy Markets of the Future; IEA Publications: Paris, 2013.

2. Cao, S.; He, F.; Gao, J.; Anti-Corros. Methods Mater. 2017, 64, 465. 
3. Iannuzzi, M.; Barnoush, A.; Johnsen, R.; NPJ Mater. Degrad. 2017, 1, 2.

4. Tissot, B. P.; Welte, D. H.; Petroleum Formation and Occurrence, $2^{\text {nd }}$ ed.; Springer-Verlag: Heidelberg, 1984.

5. ANSI/NACE, MR0175/ISO 15156-1:2015: Petroleum and Natural Gas Industries - Materials for Use in $\mathrm{H}_{2} \mathrm{~S}$-Containing Environments in Oil and Gas Production - Part 1: General Principles for Selection of Cracking-Resistant Materials; NACE International, The Corrosion Society: Houston, 2015.

6. ANSI/NACE, TM 0316-2016: Four-Point Bend Testing of Materials for Oil and Gas Applications; NACE International, The Corrosion Society: Houston, Texas, 2016.

7. ANSI/NACE, MR0175/ISO 15156-2:2015: Petroleum and Natural Gas Industries - Materials for Use in $\mathrm{H}_{2} \mathrm{~S}$-Containing Environments in Oil and Gas Production - Part 2: CrackingResistant Carbon and Low-Alloy Steels, and the Use of Cast Irons; NACE International, The Corrosion Society: Houston, Texas, 2015.

8. Smith, L.; Craig, B. In Corrosion NACexpo 2005-60 th Annual Conference \& Exposition; NACE International, The Corrosion Society: Houston, Texas, 2005

9. Craig, B.; Mater. Perform. 2002, 41, 56.

10. Singer, M.; Brown, B.; Camacho, A.; Nešić, S.; Corrosion 2011 , 67, 015004-1.

11. Kermani, M. B.; Morshed, A.; Corrosion 2003, 59, 659.

12. Yin, Z. F.; Zhao, W. Z.; Bai, Z. Q.; Feng, Y. R.; Zhou, W. J.; Electrochim. Acta 2008, 53, 3690.

13. Perez, T. E.; JOM 2013, 65, 1033.

14. Smith, S. N.; Mater. Perform. 2015, 54, 2.

15. Dugstad, A. In Corrosion NACexpo 2006 - 61 $1^{\text {st }}$ Annual Conference \& Exposition; NACE International, The Corrosion Society: San Diego, California, 2006.

16. Costa e Silva, A. L. V.; J. Mater. Res. Technol. 2018, 7, 283.

17. Papavinasam, S.; Doiron, A.; Revie, R. W.; Corrosion 2010, 66, 0350061.

18. Nyborg, R.; Dugstad, A. In Corrosion NACexpo 2003 - 58 th Annual Conference; NACE International, The Corrosion Society: San Diego, California, 2003.

19. Popoola, L. T.; Grema, A. S.; Latinwo, G. K.; Gutti, B.; Balogun, A. S.; Int. J. Ind. Chem. 2013, 4, 35.

20. Eliyan, F. F.; Alfantazi, A.; Corros. Sci. 2014, 85, 380.

21. Barker, R.; Burkle, D.; Charpentier, T.; Thompson, H.; Neville, A.; Corros. Sci. 2018, 142, 312.

22. Nejad, A. M.; Anti-Corros. Methods Mater. 2018, 65, 73.

23. Islam, M. A.; Farhat, Z.; Wear 2017, 376-377, 533.

24. Silva, M. V. F.; Pereira, M. C.; Codaro, E. N.; Acciari, H. A.; Quim. Nova 2014, 38, 293.

25. Takahashi, Y.; Matsubara, E.; Suzuki, S.; Okamoto, Y.; Komatsu, T.; Konishi, H.; Mizuki, J.; Waseda, Y.; Mater. Trans. 2005, 46, 637.

26. Smith, S. N.; Mater. Perform. 2003, $42,44$.

27. Smith, S. N. In Corrosion NACexpo 2015 - Corrosion
Conference \& Exposition; NACE International, The Corrosion Society: Dallas, Texas, 2015.

28. ANSI/NACE, TM 0284-2011: Evaluation of Pipeline and Pressure Vessel Steels for Resistance to Hydrogen-Induced Cracking; NACE International, The Corrosion Society: Houston, Texas, 2011.

29. ANSI/NACE, TM 0177-96: Laboratory Testing of Metals for Resistance to Sulfide Stress Cracking and Stress Corrosion Cracking in $\mathrm{H}_{2} \mathrm{~S}$ Environments; NACE International, The Corrosion Society: Houston, Texas, 1997.

30. Chivot, J.; Thermodynamique des Produits de Corrosion; Andra: Châtenay-Malabry, France, 2004.

31. Zhang, Y.; Pang, X.; Qu, S.; Li, X.; Gao, K.; Corros. Sci. 2012, 59, 186.

32. Neff, J.; Lee, K.; DeBlois, E. M. In Produced Water; Lee, K.; Neff, J., eds.; Springer: New York, 2011.

33. Utvik, T. I. R.; Chemosphere 1999, 39, 2593.

34. England, A. H.; Duffin, A. M.; Schwartz, C. P.; Uejio, J. S.; Prendergast, D.; Saykally, R. J.; Chem. Phys. Lett. 2011, 514, 187.

35. Skoog, D. A.; West, D. M.; Holler, F. J.; Crouch, S. R.; Fundamentals of Analytical Chemistry, $9^{\text {th }}$ ed.; Cengage: Belmont, USA, 2014.

36. Barclay, T. H.; Mishra, S.; J. Pet. Explor. Prod. Technol. 2016, 6,815 .

37. Rostami, A.; Arabloo, M.; Kamari, A.; Mohammadi, A. H.; Fuel 2017, 210, 768.

38. Pourbaix, M.; Atlas of Electrochemical Equilibria in Aqueous Solutions, $2^{\text {nd }}$ ed.; NACE International, The Corrosion Society: Houston, Texas, 1974.

39. Möller, H.; Boshoff, E. T.; Froneman, H.; J. South. Afr. Inst. Min. Metall. 2006, 106, 585.

40. Sun, W.; Nešić, S.; Young, D.; Woollam, R. C.; Ind. Eng. Chem. Res. 2008, 47, 1738.

41. Choi, Y.-S.; Nešić, S.; Ling, S.; Electrochim. Acta 2011, 56, 1752.

42. Ren, C.; Liu, D.; Bai, Z.; Li, T.; Mater. Chem. Phys. 2005, 93, 305.

43. Rickard, D.; Luther, G. W.; Chem. Rev. 2007, 107, 514.

44. Tanupabrungsun, T.; Young, D.; Brown, B.; Nešić, S. In Corrosion NACexpo 2012 - Corrosion Conference \& Exposition; NACE International, The Corrosion Society: Salt Lake City, Utah, 2011.

45. Nazari, M. H.; Allahkaram, S. R.; Kermani, M. B.; Mater. Des. 2010, 31, 3559.

46. Li, T.; Yang, Y.; Gao, K.; Lu, M.; J. Univ. Sci. Technol. Beijing 2008, 15, 702 .

47. Kahyarian, A.; Singer, M.; Nešić, S.; J. Nat. Gas Sci. Eng. 2016, 29, 530 .

48. Lemire, R. J.; Berner, U.; Musikas, C.; Palmer, D. A.; Taylor, P.; Tochiyama, O. In Chemical Thermodynamics of Iron Part 1; 
Perrone, J., ed.; OECD Nuclear Energy Agency: Issy-lesMoulineaux, 2013.

49. Silva, C. A. R.; Liu, X.; Millero, F. J.; J. Solution Chem. 2002, $31,97$.

50. Joshi, G. R.; Cooper, K.; Zhong, X.; Cook, A. B.; Ahmad, E. A.; Harrison, N. M.; Engelberg, D. L.; Lindsay, R.; Corros. Sci. 2018, 142, 110.

51. Kahyarian, A.; Brown, B.; Nešić, S.; Corros. Sci. 2017, 129, 146.

52. Shibaeva, T. V.; Laurinavichyute, V. K.; Tsirlina, G. A.; Arsenkin, A. M.; Grigorovich, K. V.; Corros. Sci. 2014, 80, 299.

53. Ochoa, N.; Vega, C.; Pébère, N.; Lacaze, J.; Brito, J. L.; Mater. Chem. Phys. 2015, 156, 198.

54. Almeida, T. C.; Bandeira, M. C. E.; Moreira, R. M.; Mattos, O. R.; Corros. Sci. 2017, 120, 239.

55. Tanupabrungsun, T.; Brown, B.; Nešić, S. In Corrosion NACexpo 2013 - Corrosion Conference \& Exposition; NACE International, The Corrosion Society: Orlando, Florida, 2013.

56. Yin, Z. F.; Feng, Y. R.; Zhao, W. Z.; Bai, Z. Q.; Lin, G. F.; Surf. Interface Anal. 2009, 41, 517.

57. Nagayassu, V. Y.; Panossian, Z.; Seckler, M. M.; Corros. Prot. Mater. 2015, 34, 42.

58. Gao, M.; Pang, X.; Gao, K.; Corros. Sci. 2011, 53, 557.
59. Nešić, S.; Corros. Sci. 2007, 49, 4308.

60. Wikjord, A. G.; Rummery, T. E.; Doern, F. E.; Owen, D. G.; Corros. Sci. 1980, 20, 651.

61. Sun, W.; Nešić, S. In Corrosion NACexpo 2007 - Corrosion Conference \& Exposition, NACE International, The Corrosion Society: Nashville, Tennessee, 2007.

62. Abelev, E.; Sellberg, J.; Ramanarayanan, T. A.; Bernasek, S. L.; J. Mater. Sci. 2009, 44, 6167.

63. Bai, P.; Zhao, H.; Zheng, S.; Chen, C.; Corros. Sci. 2015, 93, 109.

64. Pearce, C. I.; Pattrick, R. A. D.; Vaughan, D. J.; Rev. Mineral. Geochem. 2006, 61, 127.

65. Videm, K.; Kvarekvål, J.; Corrosion 1995, 51, 260.

66. Wen, X.; Bai, P.; Luo, B.; Zheng, S.; Chen, C.; Corros. Sci. 2018, 139, 124.

67. de Oliveira, M. C.; de Lima, A. P.; Figueredo, R. M.; Acciari, H. A.; Codaro, E. N.; Quim. Nova 2018, 41, 594.

68. Kittel, J.; Ropital, F.; Grosjean, F.; Sutter, E. M. M.; Tribollet, B.; Corros. Sci. 2013, 66, 324.

Submitted: February 11, 2019

Published online: April 8, 2019 